\title{
Corporate Disclosures and Financial Performance of Selected Indian Manufacturing and Non- Manufacturing Companies
}

\author{
Nidhi Sharma Sahore ${ }^{1,2} \&$ Anshul Verma ${ }^{3}$ \\ ${ }^{1}$ Assistant Professor, Bhavan’s Usha \& Lakshmi Mittal Institute of Management, New Delhi, India \\ ${ }^{2}$ Research Scholar, FMS -Mohan Lal Sukadia University, Udaipur, Rajasthan, India \\ ${ }^{3}$ Associate Professor, Institute of Management Technology (IMT) Ghaziabad, Uttar Pradesh, India \\ Correspondence: Nidhi Sharma Sahore, Bhavan’s Usha \& Lakshmi Mittal Institute of Management, Copernicus lane, \\ Kasturba Gandhi Marg, New Delhi-1, India. Tel: 98-11-522-902
}

Received: January 12, 2017

Accepted: January 25, 2017

Online Published: January 26, 2017

doi:10.5430/afr.v6n1p119

URL: http://dx.doi.org/10.5430/afr.v6n1p119

\begin{abstract}
Disclosures play a pivotal role in addressing the issues related to information asymmetry and agency costs of firms. Voluntary disclosures are those disclosures which are beyond the compulsory ones and are communicated portraying a better image of the company and its prospects in front of its investors. Therefore this study intends to extend various aspects of corporate disclosure practices, mainly voluntary disclosures of selected Indian companies. Under contract theory of economics, information asymmetry leads to superfluous decisions because of information gap between the parties. It is also important to assess the possible economic consequence of voluntary disclosures i.e. the incentive by way of enhanced firm performance. The results of the study obtained through correlation and regression approach are very encouraging and are evident of stock returns responding to corporate voluntary disclosures, financial as well as non- financial, particularly in the recent years. The effect of increased disclosures on stock prices is of possible interest to investing community and stakeholders at large including the policy makers and regulators. It is not just about the level of disclosures but also the type of disclosures e.g. non-financial disclosure like forward looking, social, and environmental which play an important role in enunciating the association between the two variables. The paper sufficiently contributes towards literature on voluntary disclosures. Its major contribution is focused towards economic consequences of disclosures by way of better stock returns and implications for Indian stock market regulator to assess the impact of its policy on manufacturing and non-manufacturing companies listed in CNX 100 index of National Stock Exchange of India.
\end{abstract}

Keywords: Voluntary disclosers, Stock Returns, Firm Performance, Voluntary Financial Disclosures, Voluntary Non-financial Disclosure

\section{Introduction}

Disclosures play a pivotal role in addressing the issues related to information asymmetry and agency costs of firms. Empirical evidence suggests that disclosures lead to reduction in information asymmetry which calls for less risk and more protection of investors on one hand while on the other hand it leads to less cost of capital for firms. The concept of disclosures in general and voluntary disclosures in particular is well elaborated by Tian and Chen (2009.) Voluntary disclosures extend and 'compliment' compulsory disclosures. Voluntary disclosures are those disclosures which are beyond the compulsory ones and are communicated portraying a better image of the company and its prospects in front of its investors. Therefore this study intends to extend various aspects of corporate disclosure practices, mainly voluntary disclosures of selected Indian companies. Under contract theory of economics, information asymmetry leads to unwarranted decisions related to transactions due to imbalanced information with the parties. Information asymmetry is a foremost reason behind apprehensions cropping up in the minds of investors due to agency problem in corporate form of business. The literature in the west focuses more on voluntary disclosures while in emerging economies of the world even the mandatory disclosures are a challenge. Therefore policy interventions are important to observe the effect of disclosures related to financial aspects as well as non-financial aspects of firm viz., Corporate Social Responsibility (CSR), Employee, Governance, Environment and Community perspectives on investor confidence when disclosures are voluntary and when they have been mandated as result of policy intervention in emerging markets (Hung, Shi and Wang, 2015). Moreover it is also important to 
assess the possible economic consequence of voluntary disclosures i.e. the incentive by way of enhanced firm performance. The effect of increased disclosures on stock prices is of possible interest to investing community and stakeholders at large including the policy makers and regulators. It is not just about the level of disclosures but also the type of disclosures, which play an important role in finding the association between the two variables. In case of firms with low analyst following forward looking information and non-financial information disclosures are more sought after while in case of firms with high analyst following information disclosures related to history and background of the firm is more looked at (Botoson, 1997.) It is a blend of 'financial' and 'non-financial' information which meets the diverse information requirements of users. The term 'non-financial' is used to refer to "information such as resources and relationships, environmental matters and management's expectations of future performance." While reporting them it needs to be ensured that a user is able to identify a clear link between an entity's business, financial performance and position (Marshall, FRC 2012.) Corporate reporting is no more considered as an expensive burden to keep the information needs of stakeholders intact. Seemingly it is a step forward because of its specific benefits to many corporate entities. This has been the main reason why eighty percent of the largest companies across 40 countries of the world have initiated sustainability reporting as per the Global Reporting Initiative (GRI) guidelines. The G8 and G20 are first among these countries to commit reforms to improve transparency and disclosures. Transparency International started this movement from oil and gas sector in 2008 and it has ever since witnessed a considerable improvement both on mandatory as well as voluntary disclosures level. Though the newer legislations have slower impact initially but that is bound to improve. It acted as a major stepping stone to build the stakeholder trust after the 2008 crisis. Disclosure of key financial data by a company enables its stakeholders to gauge tribulations earlier than the havoc (Hoyer, 2014.)

It has also been proposed in this study to check this association based on the industry type i.e., association of manufacturing and non-manufacturing firms with stock returns. Schadewitz (1997) pronounced in his study that a number of determinant independent variables used in various disclosure studies can be reduced by introducing a firm characterizing variable such as type of firm. The paper found that in case of mandatory disclosures both firm size and type have good explanatory power but in case of purely voluntary disclosures a firm's size archaized the explanatory power of firm type. This finding according to him is of great value and interest to policy makers and regulators. Hence the current study seeks to build upon this observation to find in Indian context if industry type has better explanatory power for voluntary disclosures and their association with stock returns. In order to test association between the disclosure based variables and a stock price based variable, correlation and least square regression have been approached for the all sample firms taken together at the same time, further the sample firms are divided into manufacturing and non- manufacturing firms. Varghese (2011) when linked in his study the voluntary annual report disclosures of manufacturing companies in India with firm characteristics, found that though there was a variation in disclosures done by manufacturing companies in India from 2002 to 2005 but regression analysis found non-significant relation between the nature of industry and extent of disclosures. There is no dearth of literature on disclosures and their association with the characteristics of firm, but its correlation with performance proxies like stock returns is situation specific and needs more exploration (Lang and Lundholm, 1993.) For example, Russo and Fouts (1997) found in their study that there's a positive link between economic performance and environment performance using industry as a moderator. While Yeganeh and Barzegar (2014) significantly related a firms' financial performance based upon accounting and market based proxies to corporate social responsibility disclosures in Tehran. The objective of this study is to unearth the contribution of corporate voluntary disclosures towards firm performance over a period of time starting from 2010-11 till 2014-15. Additionally it also helps us in understanding the effect of policy intervention through Clause 55 of SEBI's Listing agreement which mandated the National Voluntary guidelines issued by Ministry of Corporate Affairs (MCA) from financial year 2012-13 for top hundred companies of India by Market Cap as per the list issued by MCA.

\section{Review of Literature}

Bravo (2016), studied the financial forward looking voluntary annual report disclosures extracted through coded content analysis in order to examine their linkage with stock return volatility of Standard and Poor's 100 companies. It was found that apart from the "level of information, the interpretation and effectiveness of forward looking information depends upon the reputation of the company." The study found a significant relationship between forward looking disclosures and stock returns once again proving that annual reports are an important vehicle to communicate corporate information. This study is of special relevance to capital market regulators and managers because voluntary disclosures are a part of specific disclosure strategy for capital markets as they reduce the information gap between the firm and its investors. Besides corporate reputation various other control variables affecting the stock returns viz. trading volume, size, leverage, firm performance, firm growth, listing age, book to 
market ratio, industry have been corroborated in this study. This is because of information asymmetry which leads to stock return volatility wherein these voluntary disclosures help in smoothening out such asymmetries. Nevertheless this has been evidenced time and again in so many studies that disclosures address the issues related to information asymmetry and help in arresting agency issues. Before going ahead with findings of studies linking disclosures and stock returns, it is important to explore how disclosures have evolved over a period of time in relation to issues related to agency and information asymmetries keeping in view the various firm characteristics. In view of comprehending the need for enhanced voluntary disclosures the first half of the review of literature focuses on nature and kinds of annual report disclosures and then in the later part of the review of literature studies overarching linkages of disclosures and stock returns have been cited. The two most important works which focus on aligning the firms' interest with the interest of stakeholders are the works of Jensen and Meckling and Fama and Jensen. While Jensen and Meckling, 1976, tried to argue that accounting reports should be provided voluntarily to the creditors and stakeholders on the other hand Fama and Jensen, 1983 described how the separation of ownership and control set the blueprint for modern corporate movement and establishment of regulators like SEC in USA. Therefore communication of business information to stakeholders depends on the practices and perceptions related to effective reporting and regulations mandating the same in various countries. Bushman and Smith (2003) proposed a framework called as BPS in 2001 which conceptualized how corporate transparency can be gauged at a country level. At the same time Ho and Wong (2003) came up with a perception based study of preparer's of corporate reporting and disclosures conducted in Hong Kong and East Asian Countries. They found that choice of information to be disclosed is influenced by CEO's and CFO's. Therefore, in order to bridge the communication gap preparers suggested more voluntary disclosures instead of more disclosure regulations. Similarly, Al-Razeen and Karbhari, (2004) interestingly found concentration of voluntary disclosures in director's report section of annual reports and found no clear evidence that adhering to mandatory disclosures would mean more voluntary disclosures. Lakhal (2005) found voluntary earnings disclosures can attract more foreign institutional investor ownership. Miller (2009), observed that though increased voluntary disclosures leads to sound investment decisions by investors but certain times information is disclosed to benefit a particular category of stakeholders to increase the value of firm at the cost of others. This is neither in the public interest nor does ethical rather it stands against the stakeholder's theory which posits board and management to be responsible towards all stakeholders. Though Myring and Shortridge (2010) found a weak relation between stronger governance and enhanced disclosers but still emphasized that better governance is possible through enhanced disclosures. They further argued that more disclosures would rule out the possibility of investors and analysts relaying on idiosyncratic information.

Cooke (1989), while trying to explain the variance in the extent of disclosures by Swedish firms inferred that companies with more disclosures were either in need of capital or were subjected to some foreign regulation. In order to capture disclosure scores he created an index of 224 items encompassing financial history and information, segmental information, budgetary projections and social responsibility accounting disclosures of a firm. Craig and Diga (1998) studied a similar set of disclosures related to financial and social and non-financial aspects of business in ASEAN region. The study observed that social and non-financial disclosures were superficially disclosed by representative sample of 145 companies chosen from seven industry groups from Singapore, Malaysia, Thailand, The Philippines and Indonesia. A major gap identified by this study which prompted this current study is that there are legitimate amount of mandatory disclosures but disclosures of social and non-financial information were scarce in the sample companies from ASEAN. This reluctance to disclose information related to employment and labour, environmental activities, government subsidies, transfer pricing policies etc. was left for future studies to explore and ponder upon whether harmony in disclosure be ensured through regulations or the capital market competition is going to push the corporate disclosures towards a more voluntary regime.

Healy and Palepu (2001), in their study introduced a framework for analyzing the manager's disclosure decisions in capital market settings. Considering the changes in economic environment, financial reporting and disclosures are essential tools for management to communicate with outside investors about the governance and performance aspects of firm. Kothari and Short (2003) linked disclosures with the financial health of a firm. The companies in the selected sample were from four sectors viz., Pharmaceutical, Telecommunication, Financial Services and Technology. The study once again left a gap for potential research to be conducted on other industry sectors.

There's no doubt about the fact that firms with higher financial reporting quality can be perceived as the firms which take investor welfare seriously. Here the obvious consequence is efficient investment. The principle agent conflict between the managers and shareholders might lead to capital provided by shareholders to be parked in poor projects. A commitment to such disclosure reduces information asymmetry and lets the scarce capital contributed by investors to travel to good projects. Hence, these financial disclosures are crucial to arrest the agency problem (Verdi, 2006.) 
Zahang (2006) evidenced the potential role of accounting disclosures in addressing information uncertainty. There's an inverse relationship between enhanced accounting disclosures and information uncertainty. Also reduction in information uncertainty further leads to quicker absorption of disclosures into stock prices. The article also studied the role of firm size (market cap), age, and analyst coverage in enhancing information disclosures. The firm size, age and analyst coverage are positively correlated with each other but negatively correlated with stock volatility measured through monthly returns. But firm size as a proxy for uncertainty is negatively correlated with analyst dispersion. Schadewitz (1997) tested an interesting hypothesis stating that the variables which affect different types of disclosures also differ from each other. In order to test these hypotheses two exogenous variables i.e. index of mandatory disclosures and index of voluntary disclosures were selected where it was hypothesized that mandatory items disclosed in a report are affected by firm characteristics and not firm performance while voluntary items disclosed in a report are affected by firm's earnings but not firm characteristics. The study had seven endogenous variables viz., log of annual net sales, debt/equity ratio, ratio of change in equity/equity before change, percentage change in annual net sales, net investments to total assets ratio, Profit to net sales ratio, standard deviation of net investments to total assets ratio and possible correlated errors. This paper proposed four models through simultaneous equations. An interesting finding of the study was that the firm specific characteristics explained voluntary disclosures three times more than the mandatory ones. This paper brought forward important insights into determinants of voluntary and mandatory disclosures. Similarly, Hossain and Hammami (2009) observed that firm characteristics like age, size and asset-in-place do play an important role in explaining the extent of voluntary disclosures in an emerging economy like Qatar.

Jayshree, M. (2012), signifies the importance of disclosures in understanding the stock price volatility. It is essential to address this issue to keep the investors motivated to invest in markets. Since corporate disclosures are both mandatory and voluntary in nature which is further classified as financial as well as non-financial they need to be shared with investors on time and as per the guidelines of the market regulator. This paper hypothesizes that disclosures help to reduce stock market volatility. Hence this article studies the association between disclosures and stock markets through statistical tools like correlation and regression. The study has been conducted on BSE index companies where in stock market volatility (yearly returns) has been taken as dependent variable and disclosures have been taken to be independent variable apart from size, trading volumes, debt equity ratio and book value to market value ratio, age and return on net worth for a year i.e. 2010-11. The study did found that disclosures have impact on volatility and increased disclosures surely can help in reducing volatility as well as information asymmetry. Further Shroff, et al. (2013) highlighted the market effect of voluntary disclosure reforms on investors and capital markets. Voluntary disclosures contribute towards efficient capital markets by reducing information asymmetry and thus enhance investor protection and confidence. The Securities and Exchange Commission (SEC) relaxed Voluntary disclosure norms called Securities Offering Reform (SOR) which prompted this study to find if firms provide significantly more disclosures after SEC's reform. The study found that there is relation between voluntary disclosures and information asymmetry which affects cost of capital. Similarly a 2015 study of Russell examined continuous disclosures and information asymmetry through ordinary least square regression and two stage least square regressions. It found that more disclosures are done by firms with greater information asymmetry which further add to more information asymmetry. Hence, Apart from Financial Reporting the importance of non-financial reporting is picking up fast. Both financial and non-financial reporting is important because shareholders and various stakeholders get a holistic view of performance and position of the business. As per the latest European Union directive (2014) large public interest entities like listed companies, banks, insurance and other companies as designated by the member states with more than 500 employees should disclose information on their policies, risks and outcomes related to environmental matters, social and employee aspects, respect for human rights, anticorruption and bribery issues, and diversity in their board of directors. There's a lot of flexibility with respect to reporting these disclosures, sometimes even by way of a separate report as per national, international or European guidelines. To further guide reporting of non-financial information UN global compact, OECD guidelines, ISO 26000, ILO's Tripartite declaration concerning social policy of multinationals, Global Reporting Initiative guidelines etc. are there (Directive 2014/95/eu.)

\section{Methods}

Disclosure has been described as a latent variable i.e. which can't be observed and measured directly. Therefore it has been measured through values of other observed variables. In order to do this there are two approaches which can be followed. The first approach condenses and tries to measure it through observable characteristics while the second one identifies some variables which are assumed to have some relationship with disclosures. Hence there is huge scope for future researchers to do research and arrive at right 'constructs' which can act as explanatory 
variables (independent) to explain this phenomenon. The commonly used proxies in disclosure studies are divided into two parts i.e. proxies without recourse to original disclosure vehicle and proxies with recourse to original disclosure vehicle. The former uses disclosure surveys, existence of American depository receipts, attributes of analysts and the number of analysts following the company (using questionnaires and interviews or assigning proxies.) and the latter uses disclosure vehicles like annual reports, firm's website etc. in order to prepare disclosure Index (to measure the extent of information revealed) or do content analysis (manual as well as automated) based on frequency of information revealed. An index of disclosures can be constructed either by full involvement of a researcher where a disclosure Index is designed, constructed and scored by the researcher himself or it can be obtained from the previous studies of other researchers or can be adapted from the similar indices of professional bodies. There is no theory underlying with respect to number of items therefore items may vary from a few to more than a hundred. The reliability can be established in case of index based studies by avoiding the coding error and validity is established through hypothesis testing. Since there is no general theory to measure the disclosure aggregation therefore the sum and mean of disclosure data is important. As far as use of statistical techniques to establish causality between this latent variable (disclosure) with observable variables (independent variables/explanatory variables) a variety of tools have been used like Multiple Regression, Stepwise regression, Multivariate analysis, and Econometric techniques. However use of Structural Equation Modeling (SEM) and Confirmatory Factor models to establish the extent of incorrectly specified constructs is rare in disclosure literature. (Hassan and Marston, 2010.)

The current study focuses on voluntary annual report disclosures therefore the sample consists of CNX 100 companies which are listed on National Stock Exchange of India. The data has been manually extracted through content analysis and was binary coded for presence of voluntary disclosures as per a comprehensive voluntary discourse index specifically developed for this study over a period of five years from 2010-11 till 2014-15. This index consists of 140 items of voluntary disclosures. This comprehensive disclosure index is further sub-divided into two parts representing Voluntary Financial Disclosures and Voluntary Non-financial disclosures of the sample firms (See Table 1.)

Table 1. Items of Disclosure Index

\begin{tabular}{|c|c|c|}
\hline S. No & Category of Disclosure & No of items \\
\hline 1. & Voluntary Total Disclosure & $140(29+111)$ \\
\hline 2. & Voluntary Financial Disclosure & 29 \\
\hline 3. & $\begin{array}{l}\text { Voluntary Non-Financial Disclosure } \\
\text { Details of Voluntary Non-Financial Disclosures and } \\
\text { their respective no of items: }\end{array}$ & 111 \\
\hline 3.1 & Company Background & 13 \\
\hline 3.2 & Management and Shareholder Disclosure & 15 \\
\hline 3.3 & $\begin{array}{l}\text { Creditor and Investor Perspective: Strategic and } \\
\text { Forward looking Information also information about } \\
\text { Intangible assets }\end{array}$ & 21 \\
\hline 3.4 & $\begin{array}{l}\text { The internal process perspective, innovation and } \\
\text { learning perspective }\end{array}$ & 4 \\
\hline 3.5 & The Customer perspective & 4 \\
\hline 3.6 & The Employee Perspective & 7 \\
\hline 3.7 & $\begin{array}{l}\text { The Supplier perspective } \\
\text { The Community Perspective ( Environment, Social and } \\
\text { CSR and Sustainability) }\end{array}$ & 8 \\
\hline 3.8 & The Environment Perspective & 14 \\
\hline 3.9 & The Social Perspective & 7 \\
\hline 3.10 & The CSR and Sustainability Perspective & 18 \\
\hline \multicolumn{2}{|c|}{ Total items for Voluntary Non-Financial Disclosure } & 111 \\
\hline
\end{tabular}




\subsection{Disclosure Scores and Index Construction}

In order to go ahead with this study three disclosure based variables have been pitched one by one against annualized stock returns of constituent companies of CNX 100 index of National Stock Exchange (NSE) of India. CNX 100 is a diversified 100 stock index accounting for 38 sectors of the economy. It represented $80.81 \%$ of free float market capitalisation of the stocks listed on NSE as on June 28, 2013.The Total Trade value of CNX 100 was around 73.11\% of total traded value of all stocks on NSE for the last six months ending June 2013 (NSE, 2013.) For this study companies have been classified as Manufacturing and Non-manufacturing. Out of the total 100 companies in the sample, 64 companies are manufacturing (includes Automobile, Auto Ancillary, FMCG, Pharmaceuticals, Power, Resources and Steel producing companies) and 36 companies (includes Banks, Financial Institutions, Insurance, Information Technology, Telecom Services and Technology companies) are non-manufacturing. Following is the description of variables used in this study.

Table 2.

\section{Variable Description}

\begin{tabular}{|c|c|c|c|}
\hline \multicolumn{4}{|c|}{ Dependent Variable } \\
\hline S. No & $\begin{array}{l}\text { Variable } \\
\text { name }\end{array}$ & Description & $\begin{array}{l}\text { Nature of } \\
\text { variable }\end{array}$ \\
\hline 1. & SR & $\begin{array}{l}\text { Annualized Stock Returns (SR) as proxy for stock prices, } \\
\text { procured from Ace Equity Industrial database. } \\
\text { Independent Variables: }\end{array}$ & Scale \\
\hline 2. & VTDX & $\begin{array}{l}\text { Voluntary Total Disclosure Index (VTDX), calculated as } \\
\text { Voluntary Total Disclosure Scores = Sum of Total voluntary } \\
\text { disclosures by a company in a particular year / Total no of } \\
\text { Voluntary disclosures identified for this study in that year } \\
\text { (140.) }\end{array}$ & Scale \\
\hline 3. & VFNDX & $\begin{array}{l}\text { Voluntary Financial Disclosure Index (VFNDX), calculated } \\
\text { as Voluntary Financial Disclosure scores = Sum of Total } \\
\text { Financial disclosure by a company in a particular year / Total } \\
\text { no of disclosures in that year (29.) }\end{array}$ & Scale \\
\hline 4. & VNFDX & $\begin{array}{l}\text { Voluntary Non-Financial Disclosure Index (VNFDX), } \\
\text { calculated as Voluntary Non-Financial Disclosure scores = } \\
\text { Sum of Total Financial disclosure by a company in a } \\
\text { particular year / Total no of disclosures in that year (111.) }\end{array}$ & Scale \\
\hline
\end{tabular}

\subsection{Research Tools}

Since, most of the accounting disclosure papers make use of transformed dependent and independent variables which are proxies of underlying constructs to achieve statistically significant relations between them. Regression analysis has been commonly used across a good number of studies though multiple approaches across methods are recommended to achieve robust results (Cooke, 1998.) In order to further proceed in the current study correlation and regression have been used. Correlation and Linear Regression approach is used when an association is sought between variables and also there is a need to measure the strength of that association. Further hypothesis testing of this variation can be done to see if the association is significant or not in a setting where measurement variables can be identified as dependent and independent in order to establish cause and effect relationship (McDonald, 2015.)

\subsection{Hypothesis}

Main hypotheses: Corporate Disclosures have significant impact on Stock Prices.

Sub Hypothesis: Corporate disclosures vary across Manufacturing and Non-Manufacturing companies.

\section{Data Analysis, Results and Discussion}

Since the two variables are stock prices and the corporate disclosures in this study. Three indices have been developed by this study (VTDX, VFNDX and VNFDX) which serve as the measures of corporate disclosure while annualized stock returns (SR) have been taken to be the proxy for the stock prices. Thus the variables considered for 
the study are scale data in nature. The objective is to ascertain whether corporate disclosure have any effect on stock prices. Accordingly a two-pronged approach was resorted to.

\subsection{The Correlation Approach}

Firstly, correlation between the two variables was calculated. As the number of data points is 100 in any year, it was difficult to ascertain whether the data followed a normal distribution. Hence the calculation of coefficient of correlation was done by using both parametric and non-parametric tests. Parametric Pearsonian Coefficient of Correlation was calculated assuming a normal distribution and non-parametric Kendall's Tau-b was calculated since it is a distribution-independent test. The coefficients of correlation under both parametric and non-parametric tests have been tested for their statistical significance at $5 \%$ level of significance by framing the following hypotheses:

$\mathrm{H}_{0}: \rho=0$ i.e. there is no significant correlation between the variables

$\mathrm{H}_{1}: \rho \neq 0$ i.e. the correlation between the variables is significant.

As it was intended to have a sector-wise analysis, tests have been done considering three situations i.e. manufacturing Sector, non-manufacturing sector and both sectors taken together. Results of testing the hypotheses are contained in Table 3.

\subsubsection{Both Sectors Taken together}

VTDX and stock returns are found to have statistically significant correlation in only the last year on the basis of Pearsonian Correlation. However, based on Kendall's Tau-b test, the correlation is found to be significant in the $2^{\text {nd }}$, $4^{\text {th }}$ and $5^{\text {th }}$ years. VFNDX and stock returns are found to have no statistically significant correlation in any year on the basis of Pearsonian Correlation. However, based on Kendall's Tau-b test, the correlation is found to be significant in the $4^{\text {th }}$ year. VNFDX and stock returns are found to have statistically significant correlation in only the last year on the basis of Pearsonian Correlation. However, based on Kendall's Tau-b test, the correlation is found to be significant in the $4^{\text {th }}$ and $5^{\text {th }}$ years.

Though the correlations are significant at 5\% level of significance, the values of the coefficients are low indicating weak correlation between the variables. From the above it transpires that the correlations tend to become significant in the recent years. This indicates that stock prices, although to a low extent, have started to respond to corporate disclosure.

\subsubsection{Manufacturing Sector}

VTDX and stock returns are found to have no statistically significant correlation in any year on the basis of Pearsonian Correlation. However, based on Kendall's Tau-b test, the correlation is found to be significant only in the $4^{\text {th }}$ year. VFNDX and stock returns are found to have no statistically significant correlation in any year on the basis of Pearsonian Correlation. However, based on Kendall's Tau-b test, the correlation is found to be significant in the $3^{\text {rd }}$ year. VNFDX and stock returns are found to have no statistically significant correlation in any year on the basis of Pearsonian Correlation. However, based on Kendall's Tau-b test, the correlation is found to be significant in the $5^{\text {th }}$ year only. Though the correlations are significant at $5 \%$ level of significance, the values of the coefficients are low indicating weak correlation between the variables.

From the above it can be seen that the correlations tend to become significant in the recent years with significant correlations mostly in the $5^{\text {th }}$ year. This corroborates the fact that stock prices, although to a low extent, have started to respond to corporate disclosure. One more significant observation can be had from the above results. Low correlation between corporate disclosure and stock returns indicate presence of other factors which affect stock returns. This finding calls for a corroborative study using linear regression approach.

\subsubsection{Non-manufacturing Sector}

VTDX and stock returns are found to have no statistically significant correlation in any year on the basis of Pearsonian Correlation as well as on the basis of Kendall's Tau-b test. VFNDX and stock returns are found to have statistically significant correlation in the $4^{\text {th }}$ year on the basis of Pearsonian Correlation. However, based on Kendall's Tau-b test, the correlation is found to be significant in the $2^{\text {nd }}$ and $4^{\text {th }}$ years. VNFDX and stock returns are found to have no statistically significant correlation in any year on the basis of Pearsonian Correlation as well as on the basis of Kendall's Tau-b test. Though the correlations are significant at 5\% level of significance, the values of the coefficients are low indicating weak correlation between the variables. From the above it can be seen that the correlations tend to become significant in the recent years with significant correlations mostly in the $4^{\text {th }}$ year. This further corroborates the fact that stock prices, although to a low extent, have started to respond to corporate 
disclosure. On a comparative basis, correlation between stock returns and corporate disclosure has not been found to be different prima-facie between manufacturing and non-manufacturing sectors.

Table 3. Main Hypotheses testing - Correlation Approach

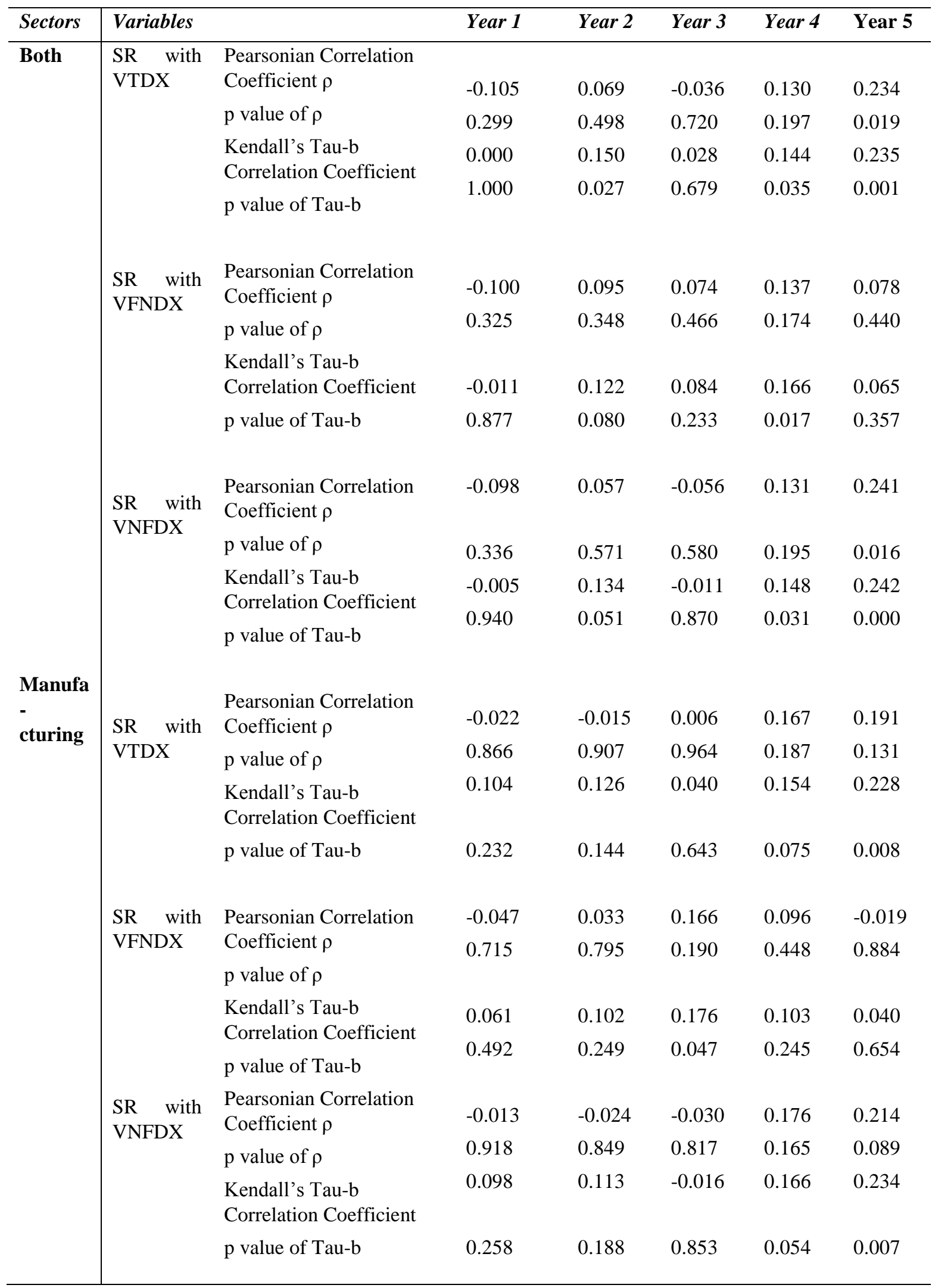




\begin{tabular}{|c|c|c|c|c|c|c|c|}
\hline \multirow[t]{12}{*}{$\begin{array}{l}\text { Non-M } \\
\text { anufa-c } \\
\text { turing }\end{array}$} & \multirow{4}{*}{$\begin{array}{l}\text { SR with } \\
\text { VTDX }\end{array}$} & Pearsonian Correlation & -0.238 & 0.228 & -0.160 & 0.064 & 0.327 \\
\hline & & Coefficient $\rho$ & 0.169 & 0.181 & 0.352 & 0.710 & 0.051 \\
\hline & & $p$ value of $\rho$ & -0.181 & 0.176 & -0.002 & 0.082 & 0.239 \\
\hline & & $\begin{array}{l}\text { Kendall's Tau-b } \\
\text { Correlation Coefficient } \\
p \text { value of Tau-b }\end{array}$ & 0.134 & 0.134 & 0.989 & 0.487 & 0.042 \\
\hline & \multirow{4}{*}{$\begin{array}{l}\text { SR with } \\
\text { VFNDX }\end{array}$} & $\begin{array}{l}\text { Pearsonian Correlation } \\
\text { Coefficient } \rho\end{array}$ & -0.211 & 0.294 & -0.260 & 0.329 & 0.274 \\
\hline & & $p$ value of $\rho$ & 0.223 & 0.082 & 0.126 & 0.050 & 0.106 \\
\hline & & $\begin{array}{l}\text { Kendall's Tau-b } \\
\text { Correlation Coefficient }\end{array}$ & -0.170 & 0.250 & -0.123 & 0.299 & 0.141 \\
\hline & & $p$ value of Tau-b & 0.168 & 0.037 & 0.304 & 0.013 & 0.243 \\
\hline & \multirow{4}{*}{$\begin{array}{l}\text { SR with } \\
\text { VNFDX }\end{array}$} & Pearsonian Correlation & -0.228 & 0.204 & -0.126 & 0.021 & 0.310 \\
\hline & & $\begin{array}{l}\text { Coefficient } \rho \\
p \text { value of } \rho\end{array}$ & 0.187 & 0.232 & 0.465 & 0.903 & 0.066 \\
\hline & & Kendall's Tau-b & -0.181 & 0.154 & 0.000 & 0.034 & 0.229 \\
\hline & & $p$ value of Tau-b & 0.134 & 0.191 & 1.000 & 0.775 & 0.051 \\
\hline
\end{tabular}

\subsection{The Linear Regression Approach}

The regression approach is used to find out how much of the changes in stock prices are explained by corporate disclosure. Linearity is assumed to filter out the numerous options under assumptions of non-linearity. Corporate disclosure, represented by the three indices developed in this study i.e. VTDX, VFNDX and VNFDX, are taken to be the predictor variables and stock prices, represented by stock returns, is considered to be the dependent variable. The $\mathrm{R}^{2}$ values are calculated which provides us with the proportion of change in the dependent variable which is explained by the change in the predictor variable. The intercept $\alpha$ and the coefficient of the predictor variable $\beta$ along with their $p$ values is calculated. The statistical significance of the values of $\beta$ is tested at $5 \%$ level of significance by framing the following hypotheses:

$\mathrm{H}_{0}: \beta=0$ i.e. the coefficient of the predictor variable is not significant

$\mathrm{H}_{1}: \beta \neq 0$ i.e. the coefficient of the predictor variable is significant

As it was intended to have a sector-wise analysis, tests have been done considering three situations i.e. manufacturing Sector, non-manufacturing sector and both sectors taken together. Results of testing the hypotheses are contained in Table 4.

\subsubsection{Both Sectors Taken together}

For VTDX as the predictor variables, the $\mathrm{R}^{2}$ values have shown a steady increase over the years indicating increased proportions of the changes in the dependent variable being explicable by the changes in the predictor variable. This trend is supported by the fact that the value of $\beta$ has become significant in the $5^{\text {th }}$ year. For VFNDX as the predictor variables, the $\mathrm{R}^{2}$ values have shown a steady increase over the years indicating increased proportions of the changes in the dependent variable being explicable by the changes in the predictor variable till the $4^{\text {th }}$ year. Though the value took a dip in the $5^{\text {th }}$ year, the overall trend reflects a rising trend over the years. However the $\beta$ values failed to be statistically significant in any of the years. For VNFDX as the predictor variables, the $\mathrm{R}^{2}$ values have shown a steady increase over the years indicating increased proportions of the changes in the dependent variable being explicable by the changes in the predictor variable. This trend is supported by the fact that the value of $\beta$ has become significant in 
the $5^{\text {th }}$ year. Though the $\mathrm{R}^{2}$ values are low not exceeding $10 \%$, the trend is clear that corporate disclosure has increasingly become important in affecting the stock returns.

From the findings as mentioned above, it is thus established that as time goes by, the stock returns get affected by corporate disclosure. The low values of $\mathrm{R}^{2}$ are obvious as stock returns are dependent on various other macro-economic factors and company fundamentals.

\subsubsection{Manufacturing Sector}

For VTDX as the predictor variables, the $\mathrm{R}^{2}$ values have shown an increase over the years, especially in the $4^{\text {th }}$ and $5^{\text {th }}$ years after zero values in the first three years indicating increased proportions of the changes in the dependent variable being explicable by the changes in the predictor variable. However the $\beta$ values failed to be statistically significant in any of the years. For VFNDX as the predictor variables, the $\mathrm{R}^{2}$ values have shown a cap-shaped movement over the years with a rise followed by a fall thereafter over the years indicating increased proportions of the changes in the dependent variable being explicable by the changes in the predictor variable till the $3^{\text {rd }}$ year and a steady fall in the subsequent two years. However the $\beta$ values failed to be statistically significant in any of the years. For VNFDX as the predictor variables, the $\mathrm{R}^{2}$ values have shown a steady increase over the years indicating increased proportions of the changes in the dependent variable being explicable by the changes in the predictor variable. However the $\beta$ values failed to be statistically significant in any of the years. Though the $\mathrm{R}^{2}$ values are low not exceeding $3.10 \%$, the trend is clear that corporate disclosure represented by VTDX and VNFDX has increasingly become important in affecting the stock returns. From the findings as mentioned above, it is thus established that as time goes by, the stock returns get affected by corporate disclosure. The low values of $\mathrm{R}^{2}$ are obvious as stock returns are dependent on various other macro-economic factors and company fundamentals.

Table 4. Main Hypotheses testing - Linear Regression Approach

\begin{tabular}{|c|c|c|c|c|c|c|c|}
\hline Year & Companies & $\begin{array}{l}\text { Stock Returns (SR) with } \\
\text { disclosure indices. }\end{array}$ & $\mathrm{R}^{2}$ & $\alpha$ & $\begin{array}{l}\mathrm{p}-\mathrm{Val} \\
\alpha\end{array}$ & $-\beta$ & $\begin{array}{l}\text { p-Val }-\beta \\
\text { and p-Val } \\
\text { of } \\
\text { Statistic }\end{array}$ \\
\hline \multirow[t]{9}{*}{1} & \multirow[t]{3}{*}{ All } & SR-VTDX & 0.001 & 31.150 & 0.000 & -14.16 & 0.299 \\
\hline & & SR-VFNDX & 0.010 & 31.513 & 0.000 & -13.993 & 0.325 \\
\hline & & SR-VNFDX & 0.010 & 30.100 & 0.000 & -11.848 & 0.336 \\
\hline & \multirow[t]{3}{*}{ Manufacturing } & SR-VTDX & 0.000 & 27.152 & 0.001 & -3.085 & 0.866 \\
\hline & & SR-VFNDX & 0.002 & 28.634 & 0.001 & -6.215 & 0.715 \\
\hline & & SR-VNFDX & 0.000 & 26.564 & 0.001 & -1.718 & 0.918 \\
\hline & \multirow[t]{3}{*}{ Non-Manufacturing } & SR-VTDX & 0.056 & 35.888 & 0.000 & -29.161 & 0.169 \\
\hline & & SR-VFNDX & 0.045 & 38.486 & 0.003 & -32.507 & 0.223 \\
\hline & & SR-VNFDX & 0.052 & 33.974 & 0.000 & -25.000 & 0.187 \\
\hline \multirow[t]{6}{*}{2} & \multirow[t]{3}{*}{ All } & SR-VTDX & 0.005 & 10.474 & 0.175 & 11.844 & 0.498 \\
\hline & & SR-VFNDX & 0.009 & 7.160 & 0.434 & 18.556 & 0.349 \\
\hline & & SR-VNFDX & 0.003 & 11.781 & 0.087 & 8.831 & 0.569 \\
\hline & \multirow[t]{3}{*}{ Manufacturing } & SR-VTDX & 0.000 & 21.365 & 0.061 & -2.915 & 0.908 \\
\hline & & SR-VFNDX & 0.001 & 17.186 & 0.158 & 6.722 & 0.796 \\
\hline & & SR-VNFDX & 0.001 & 21.896 & 0.032 & -4.250 & 0.850 \\
\hline
\end{tabular}




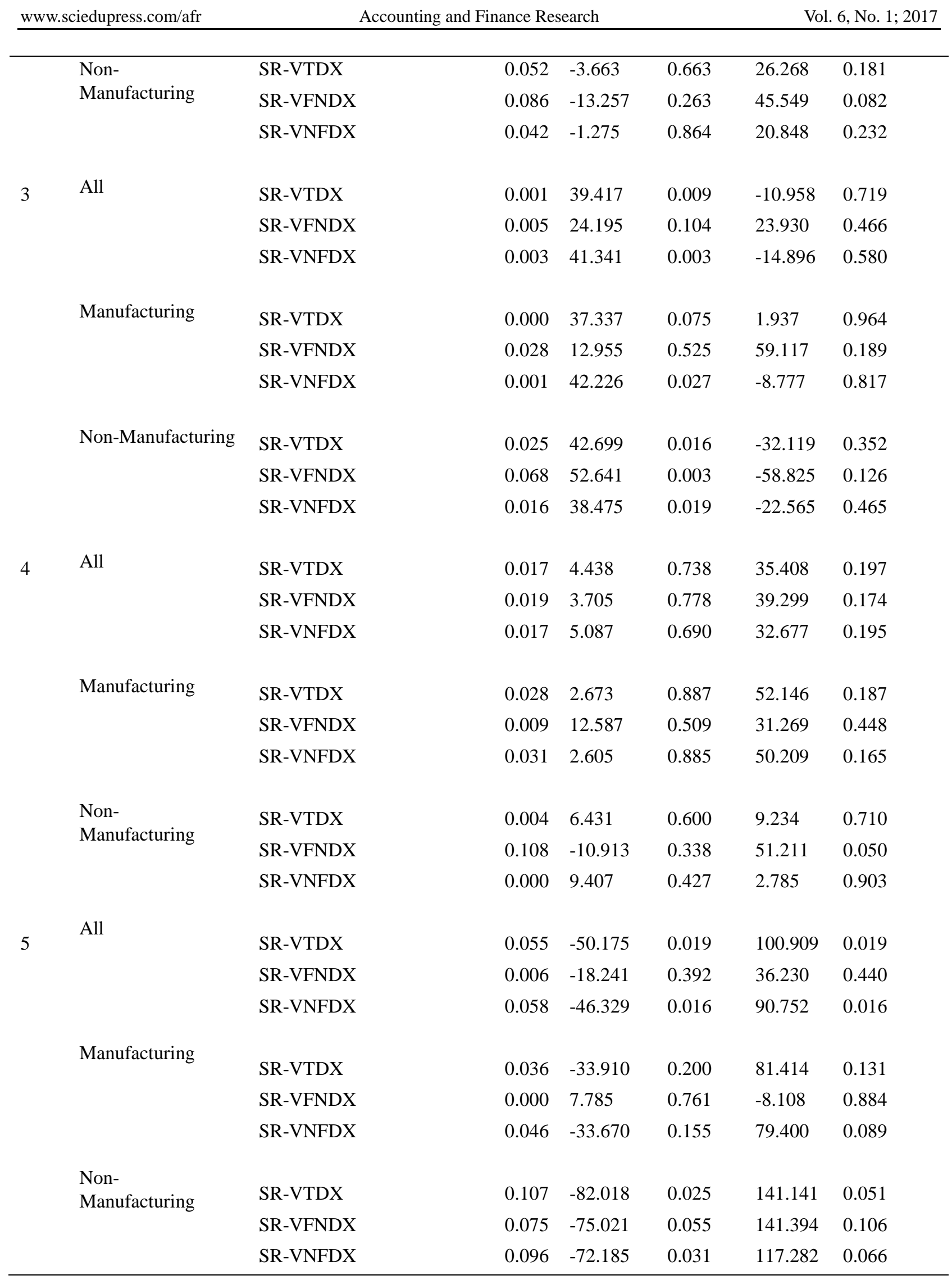




\subsubsection{Non-manufacturing Sector}

For VTDX as the predictor variables, the $\mathrm{R}^{2}$ values have shown an increase over the years, especially in the $5^{\text {th }}$ year, indicating increased proportions of the changes in the dependent variable being explicable by the changes in the predictor variable. This is supported by the fact that the $\beta$ value became almost significant in the $5^{\text {th }}$ year. For VFNDX as the predictor variables, the $\mathrm{R}^{2}$ values have exhibited somewhat increasing trend indicating increased proportions of the changes in the dependent variable being explicable by the changes in the predictor variable over the study period of 5 years. However though the $\beta$ value became significant in the $4^{\text {th }}$ year, it lost its significance in the $5^{\text {th }}$ year. These values of $\beta$ correspond to the movements of the $\mathrm{R}^{2}$ values. For VNFDX as the predictor variables, the $\mathrm{R}^{2}$ values have shown a steadily falling trend till the $4^{\text {th }}$ year where after it exhibited a steep rise in the $5^{\text {th }}$ year indicating decreased proportions of the changes in the dependent variable being explicable by the changes in the predictor variable followed by a steep rise thereof in the $5^{\text {th }}$ year. This behavior of the $\mathrm{R}^{2}$ values is supported by the $\beta$ values which became almost significant in the $5^{\text {th }}$ year. Though the $\mathrm{R}^{2}$ values are low not exceeding $9.60 \%$, the trend is clear that corporate disclosure has increasingly become important in affecting the stock returns. From the findings as mentioned above, it is thus established that as time goes by, the stock returns get affected by corporate disclosure. The low values of $\mathrm{R}^{2}$ are obvious as stock returns are dependent on various other macro-economic factors and company fundamentals.

\section{Conclusion}

The objective of this study is to ascertain whether corporate disclosure have any effect on stock prices. Corporate disclosures by a firms has been transformed into three disclosures VTDX, VFNDX and VNFDX representing Voluntary total disclosures by a firm, voluntary financial disclosures and voluntary non-financial disclosures by a firm respectively. Further it is intended to have analysis tests sector-wise considering three antecedents i.e. manufacturing Sector, non-manufacturing sector and both sectors taken together. Data has been analyzed using correlation and regression approaches. Prima-facie correlations between stock returns and corporate disclosure have not been found to be different between manufacturing and non-manufacturing firms. But, when both sectors were taken together correlations between stock returns and VTDX and VNFDX became significant in recent years. In non-manufacturing firms VFNDX significantly associated with stock returns in later years. In case of manufacturing firms the correlations became significant in last year i.e. $5^{\text {th }}$ year which prompted us to go ahead with a corroborative study using linear regression approach. Considering both sectors together through the regression was weak but there was a steady increase in $\mathrm{R}^{2}$ values over a period of five years. VTDX and VNFDX became significant by the $5^{\text {th }}$ year. In case of manufacturing firms, corporate disclosures represented by VTDX and VNFDX have increasingly become important in affecting the stock returns. Similar was the case of non-manufacturing companies where VTDX and VNFDX are almost significant in the fifth year. The trend is clear that corporate disclosures have increasingly become important in affecting the stock returns. The low values of $\mathrm{R}^{2}$ are obvious as stock returns are dependent on various other macro-economic factors and company fundamentals. But the main finding of this paper is that the corporate disclosures do respond to stock returns especially voluntary non financial disclosures. This study has definite implications by way of contributing to existing literature as the findings are based on time period as recent as year 2014-15. Policy makers like Ministry of Corporate Affairs (MCA) which introduced National Voluntary Guidelines (NVGs) in 2011 and kept disclosure under them voluntary till 2011-12 and mandated them for top 100 Indian companies by market cap from 2012-13 onwards are bound to gain insights through the findings of this study. Last but not the least the stock market regulator SEBI which introduced in the same year clause 55 of listing agreement for the same set of top companies to disclose more non-financial information in annual reports may find this disclosure assessment and analysis of value as it leads to bridging the information gap between the firms and investors. This study is also of relevance to industry at large because disclosures not just lead to reduction in information asymmetries between the firms and capital providers but also have definite economic consequences by way of a trend of stock returns responding to disclosures by firms manufacturing as well as non-manufacturing. The paper contributes towards literature on voluntary disclosures. Its major contribution is focused towards economic consequences of disclosures by way of better stock returns, as enhanced and prolonged voluntary disclosures reduce information asymmetry and thus enhance investor confidence and protection (Shroff et al. 2013.) The study can be extended to study the same variables against other economic consequence proxies like profitability of firm in the presence of firm characteristics. 


\section{References}

Al-Razeen, A., \& Karbhari, Y. (2004). Interaction between compulsory and voluntary disclosure in Saudi Arabian corporate annual reports. Managerial Auditing Journal, $19(3), \quad 351 \quad-\quad 360$. https://doi.org/10.1108/02686900410524364

Botoson, C. (1997). Disclosure level and the Cost of Equity Capital. The Accounting Review, 72 (3), $323-349$.

Bravo, F. (2016). Forward-looking Disclosure and Corporate Reputation as Mechanisms to Reduce Stock Return Volatility. Spanish Accounting review, 19(1), 122-131.

Bushman, R., \& Smith, A. (2003). Transparency, Financial Accounting Information and Corporate Governance. Economic Policy Review, 9(1), 65-87.

Cooke, T. (1998). Regression analysis in Accounting Disclosure Studies, Accounting and Business Research, 28(3), 209-224. https://doi.org/10.1080/00014788.1998.9728910

Cooke. T. (1989). Disclosure in the corporate annual reports of Swedish companies. Accounting and Business Research, 19(74), 113-124, 124, https://doi.org/10.1080/00014788.1989.9728841

Craig, R., \& Diga, J. (1998). Corporate Accounting Disclosure in ASEAN. Journal of International Financial Management and Accounting, 9(3), 246-274. https://doi.org/10.1111/1467-646X.00039

European Commission, (2014). Directive 2014/95/eu of the European Parliament and of the Council amending Directive 2013/34/EU as regards disclosure of non-financial and diversity information by certain large undertakings and groups, Retrieved from EUR-Lex website http://eur-lex.europa.eu/legal content/EN/ALL/?uri=CELEX:32014L0095\&qid=1430238231690

Fama, E. \& Jensen, M. (1983). Separation of Ownership and Control. Journal of Law and Economics, XXVI. https://doi.org/10.1086/467037

Hassan, O. \& Marston, C. (2010). Disclosure Measurement in the empirical accounting Literature: A Review Article. Economics and Finance Working Paper Series, working paper No. 10-18, Brunell University West London.

Healy, P. \& Palepu K. (2001). Information asymmetry, corporate disclosure, and the capital markets: A review of the empirical disclosure literature. Journal of Accounting and Economics, 31(1-3), 405-440. https://doi.org/10.1016/S0165-4101(01)00018-0

Ho, S. \& Wong, S. (2003), Preparers perceptions of corporate reporting and Disclosures. International Journal of Disclosure and Governance, 1(1), 71-81. https://doi.org/10.1057/palgrave.jdg.2040014

Hossain, M. \& Hammami, H. (2009). Voluntary disclosures in the annual reports of an emerging country: The case of Qatar, Advances in accounting incorporating advances in international accounting, 25, 255-265, https://doi.org/10.1016/j.adiac.2009.08.002

Hoyer, B. (2014). Transparency in corporate reporting; assessing the worlds largest companies, Retrieved from Transparency International website: http://www.transparency.org/whatwedo/publication/transparency_in_corporate_reporting_assessing_worlds_lar gest_companies_2014

Hung, C., Shi, J., \& Wang, Y. (2015). Mandatory CSR Disclosure and Information Asymmetry: Evidence from a Quasi-natural Experiment in China, The Asian Finance Conference 2013, The second symposium on China's Financial Markets and The 13th annual strategy and business environment conference at UT Austin.

Jayshree, M. (2012). Disclosure and stock price volatility: A study of Indian stock market. The International Journal of Management, 1(3).

Jensen, M., \& Meckling, W. (1976). Theory of Firm: Managerial Behaviour, agency Costs and ownership Structure. Journal of Financial Economics, 3(4), 305-360. https://doi.org/10.1016/0304-405X(76)90026-X

Kothari, S. and Short, J. (2003). The Importance of Corporate Disclosures: How Market Transparency Affects the Firm's Financial Health. Centre for eBusiness, II(2).

Lakhal, F. (2005). Voluntary Earnings Disclosures and Corporate Governance: Evidence from France. Review of Accounting and Finance, 4(3), 64. https://doi.org/10.1108/eb043431

Lang, M., \& Lundholm, R. (1993). Cross-Sectional Determinants of Analyst Ratings of Corporate Disclosures. Journal of Accounting Research, 31(2), 246-271. https://doi.org/10.2307/2491273 
Marshall, R., FRC (2012). Thinking about disclosures in a broader context, a roadmap for disclosure framework, London, England, Retrieved from The Financial Reporting Council Limited website: https://www.frc.org.uk/getattachment/99bc28b2-c49c-4554-b129-9a6164ba78dd/Thinking-about-disclosures-ina-broader-contex.aspx

McDonald, H. (2014). Handbook of Biological Statistics (3rd ed.), Sparky House Publishing, Baltimore, Maryland retrieved on 27/12/16, http://www.biostathandbook.com/linearregression.html.

Miller, S. (2009). Opportunistic Disclosures of Earnings forecasts and Non-GAAP earnings measures. Journal of Business Ethics, 89(3), 10. https://doi.org/10.1007/s10551-008-9903-0

Myring, M., \& Shortridge, T. (2010). Corporate Governance and Quality of Financial Disclosures. The International Business and Economic Research Journal, 9(6), 103. https://doi.org/10.19030/iber.v9i6.589

NSE (National stock Exchange of India Ltd.), 2013, http://www.nseindia.com/products/content/equities/indices/cnx_100.htm, retrieved on 8 August, 2013.

Russell, M. (2015). Continuous disclosure and information Asymmetry. Accounting Research Journal, 28(2), 195 224. https://doi.org/10.1108/ARJ-11-2013-0085

Russo, M. \& Fouts, P. (1997). A Resource-Based Perspective On Corporate Environmental Performance And Profitability. ACAD MANAGE J, 40(3), 534-559, https://doi.org/10.2307/257052

Schadewitz, H. \& Kanto, A. (1997). A multidimensional model for the disclosure policy of a firm. Scandinavian Journal of Management, 13(3), 229-249. https://doi.org/10.1016/S0956-5221(97)00007-9

Shroff, N. et. al. (2013). Voluntary disclosure and Information Asymmetry: Evidence from 2005 Securities Offering Reform 2005. Journal of Accounting Research, 51(5).

Tian, Y., \& Jingliang, C. (2009). Concept of Voluntary Information Disclosure and A Review of Relevant Studies. International Journal of Economics and Finance, 1(2). https://doi.org/10.5539/ijef.v1n2p55

Varghese, R. (2011). Voluntary Annual report Disclosures of Manufacturing Companies in India and their Linkages with Organizational Demographics. South Asian Journal Of Management, 18(4), 23.

Verdi, R. (2006). Financial reporting quality and Investment efficiency, The Wharton School, University of Pennsylvania. https://doi.org/10.2139/ssrn.930922

Yeganeh, Y. and Barzegar, G. (2014). The Effect of Disclosure Level of Corporate Social Responsibility (CSR) on Corporate Financial Performance (CFP) in Tehran Stock Exchange. International Journal of Accounting Research, 1(11), 43.

Zahang, X. (2006). Information uncertainty and stock return. The Journal of Finance, IXI(1). 